\title{
Dumitru Loșonți, Certitudini și ipoteze etimologice, Editura Academiei Române, București, 2007, 187 p.
}

\author{
Dinu Moscal ${ }^{*}$ \\ "A. Philippide" Institute of Romanian Philology, Str. Th. Codrescu 2, 700481 Iași, Romania
}

The study of the reputed Romanian etymologist from Cluj is dedicated to the etymology of an inventory of words belonging mainly to the regional lexis, words that are either not listed at all in dictionaries or are listed under the wrong etymology, with insufficient etymological explanations or simply labelled with unknown etymology. The later case often applies to the inaccurate borrowing of the form or of the indication referring to meaning from the research documents or even from the series of Atlasul lingvistic român [The Romanian Linguistic Atlas], which the author checks or re-interprets according to their pronunciation in the dialectal area from where the term originates and the way in which the pronunciation should be spelled. The dictionaries mentioned by the author often start from the wrong form, which leads either to the formation of words which do not actually exist in the language or to the wrong interpretation of the meaning, which ultimately denies all the premises for an accurate etymology. The dictionary which is most often quoted in connection to these issues is Micul Dicționar Academic [The Small Academic Dictionary], yet Dicționarul explicativ al limbii române [The Romanian Language Explanatory Dictionary] and Dicționarul limbii române [The Romanian Language Dictionary] are also mentioned. Besides problems related to form and meaning, the author draws our attention towards the other basic aspects specific to the complex nature of etymological explanation: accurate spelling, which needs a dialectologist's expert advice, as well as the danger of involving a lexicographer in completing the information by means of deductions related to the general system of the Romanian language, such as creating the plural according to the singular form provided by the source, placing the accent or specifying the gender or number although these indications do not appear in the source and creating lexical classes starting from verbs, from which nouns and adjectives result even if they do not appear in the glossaries or atlases used before. Besides the issues mentioned in the Foreword, the explanations in the etymological articles (which form the main body of the work) indicate other possible wrong directions in etymological analysis, out of which we must mention the wrong interpretation of certain proper names (which are in certain cases regarding as appellatives) or the wrong perception at the syntactic level. The study refers to just a small proportion of the "(intolerable) high number of such "words"” (p. 5), if we consider those that are practically inexistent while also taking into account a series of words involving various other types of etymological problems.

The study is structured in three parts: Note etimologice [Etymological notes], Etimologii puşcariene controversate (I) [Controversial etymologies provided by Puşcariu (I)] and Creații românești sau cuvinte moştenite? (I) [Romanian creations or inherited words? (I)], the specifications in the first two parts indicating that a new series will follow. Most cases deal with etymological certitudes, yet hypotheses are always well-documented, the last two parts being rather included in the second category.

We must mention a few situations which are illustrative for the issues under discussion, without indicating the page number and only mentioning the words in the title, as these are to be found in the glossary at the end of the paper.

As far as observations regarding dialectal phonetic variation are concerned, we came across: inaccurate interpretation and wrong spelling of the phonetic transcript in the case of bilabial occlusive palatalization $\left(-g^{\prime}\right.$ for $-b i$, wrongly interpreted as $-g i$, in bărgi,


tion of pre-palatal affricates fricativization (fricative with slightly anterior pronunciation, variant of pre-

\footnotetext{
*Email address: dinumoscal@yahoo.com.
} 
palatal affricate $-\hat{c}-$ is rendered through $-s-$, without identifying the notation of the pronunciation $-s^{-}$, specific to the Criş area, so that the spelling moşioacă is provided instead of mocioacă, version of bocioacă), misinterpretation of palatalized dental occlusives ( $t^{\prime}-$ transcribed chi- in cheasc, instead of teasc; cheglă instead of teglă, and so on).

In other instances we are being warned against wrong semantic interpretations in the case of lexical derivation which implies the transition from one verbal category to the other ("development" in Coseriu's terms). Thus, derivates such as blegeală or cărbuneală cannot result from the category of substance, designated by the noun (bleg, cărbune), but they result from the category of action, designated by the verb (blegi, cărbuni).

Among the cases of careless interpretation of a grapheme we can only mention a few examples: the meaning 'copac' ['tree'] instead of 'capac' ['lid'] in the previously mentioned cheasc (instead of teasc), bănte instead of băuțe (plural of băuţă), chiedeu instead of pieden (from the kéden version), bablină instead of cablină.

Besides signalling these deviations the study often focuses on explanations upon the regular phonetic evolutions (bagică, baramoi), without which certain words are even listed as having unknown etymology (boroscodenie), the indication of another etymon (băbălugăa căntăli,ştiftă) or of a version of what the authors of the dictionaries mentioned above supposed to be accurate (dolmaci), issues related to the history of the Romanian language (occurrence of the suffix -ier in the Romanian language, cf. bărbier), the misinterpretation of proper names as appellatives (cercurica, cercuriu; colțuna, ghio (a)ca), issues of spoken language syntax interpretation (corsur instead of corbi suri) or other details regarding the evolution and variation of the language that can lead to inaccurate etymological explanations unless properly comprehended.

Among the articles in the first part, the most remarkable as far as the argumentation is concerned are the ones for jijican, odaie and fulă (inherited from Latin, unknown to dictionaries). The etymological argumentations in the last two parts are equally remarkable, as the author rehabilitates a few etymologies proposed by Pușcariu (in the second part) and brings arguments for interpreting certain words as inherited ones rather than as Romanian creations.

Certitudini și ipoteze etimologice [Etymological certainties and hypotheses] offers the reader not only etymologies, but an adequate method which is different from all other common approaches and interpretations. The explanations are almost always enough for the expert reader, who could doubt some of the proposed hypotheses, but could not raise any objection with regard to them. 